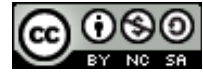

https://doi.org/10.31743/abmk.5810

WOJCIECH ZIOBRO* - RZESZÓW

\title{
KSIĄDZ AUGUST NAHLIK (1812-1878). PROBOSZCZ STRZYŻOWSKI Z KONSPIRACYJNĄ PRZESZLOŚCIĄ
}

\begin{abstract}
Streszczenie
W artykule przybliżone zostały mało znane losy księdza Augusta Nahlika (18121878) z czasów, kiedy sprawował on probostwo w parafii pw. św. Katarzyny w Rumnie. Zaangażował się tam bowiem w ruch niepodległościowy, a następnie stał się jedną z czołowych postaci tzw. spisku w Horożannie, którego głównym celem było wywołanie w Galicji Wschodniej lokalnego powstania skierowanego przeciwko zaborcom. Wspólnie z innymi tego typu wystąpieniami na terenie całej Galicji spisek w Horożannie miał stać się ważnym ogniwem w przygotowywanym od lat 40. XIX wieku przez Towarzystwo Demokratyczne Polskie ogólnonarodowym zrywie niepodległościowym. Niestety, w 1846 r. spisek ten został wykryty i krwawo stłumiony przez chłopów, a same zaś zajścia w Horożannie łączone są $\mathrm{z}$ rozgrywającymi się $\mathrm{w}$ tym samym czasie wydarzeniami określanymi przez historiografię mianem rabacji galicyjskiej. Ks. Nahlik wraz z innymi spiskowcami, którym udało się ujść z życiem przed cepami i kosami chłopów, skazany został na 15 lat pobytu w jednym z najcięższych ówcześnie więzień Cesarstwa Austrii - twierdzy Spielberg. Jednak dzięki ogłoszonej w 1848 r. amnestii odzyskał wolność i po rocznej suspensie skierowany został najpierw na probostwo do parafii pw. św. Wawrzyńca w Chyrowie, a następnie w 1864 r. przeniesiony został na zachodnie krańce diecezji przemyskiej do parafii pw. Niepokalanego Poczęcia NMP i Bożego Ciała w Strzyżowie, która była ostatnią placówką duszpasterską na drodze ks. Nahlika. Zarządzał nią bowiem aż do swojej śmierci w 1878 r. Treść artykułu wzbogaca ponadto edycja ostatniej woli ks. Nahlika z 1878 r., która zachowała się w aktach notarialnych Feliksa Misky’ego, a także fotografia księdza pochodząca ze zbiorów Polskiej Akademii Nauk.

Słowa kluczowe: parafia Strzyżów; proboszcz; Galicja; testament; ruch niepodległościowy; rabacja galicyjska; Galicja Wschodnia; August Nahlik
\end{abstract}

* Wojciech Ziobro - mgr historii; doktorant w Instytucie Historii; Uniwersytet Rzeszowski e-mail: ziobrowj@gmail.com

https://orcid.org/0000-0003-1269-2692 
Przeglądając akta notariuszy strzyżowskich z lat 1873-1947 zgromadzone w Archiwum Państwowym w Przemyślu, natrafić można na wiele dokumentów, które w znaczący sposób umożliwiają poznanie zarówno życia codziennego, jak i kwestii majątkowych mieszkańców regionu. Wśród tych dokumentów na uwagę zasługuje sporządzony w kancelarii notariusza Feliksa Misky'ego w 1878 r. testament ks. Augusta Nahlika, proboszcza parafii pw. Niepokalanego Poczęcia NMP i Bożego Ciała w Strzyżowie w latach 1864-1878. Jego edycja jest doskonałą okazją do przybliżenia nie wszystkim do końca znanej sylwetki duchownego ${ }^{1}$. Zapisał się on bowiem nie tylko na kartach lokalnej historii, jako dobrze dbający o swoją parafię duszpasterz, ale i tej ogólnonarodowej, aktywnie angażując się w działalność niepodległościową. Zasłużył sobie tym na osobne miejsce wśród wybitnych osobistości tego okresu, czego przykładem może być życiorys w Polskim Stowniku Biograficznym ${ }^{2}$.

Przedstawienie testamentu jest także doskonałą okazją do przybliżenia wizerunku księdza, zachowanego na fotografii z lat 60. XIX wieku, która przechowywana jest obecnie w zbiorach Polskiej Akademii Nauk ${ }^{3}$.

August Nahlik urodził się w 1812 r. w Modryczu niedaleko Drohobycza. Jego ojcem był Karol (1773-1834), osiadły w Galicji Czech, zarządca drohobyckich salin i właściciel kilku kamienic we Lwowie. Matką zaś baronówna francusko -węgierskiego pochodzenia Karolina (1782-1858), córka pułkownika armii austriackiej Benwentuta Losy de Losenaua, wywodzącego się ze starej szlachty lotaryńskiej. Miał jedenaścioro rodzeństwa, w tym sześć sióstr (Albertynę, Augustę, Franciszkę, Julię, Karolinę i Marię Ludwikę) i pięciu braci (Alberta, Franciszka, Juliusza, Karola i Ludwika) ${ }^{4}$.

\footnotetext{
${ }^{1}$ Ks. Nahlik pojawia się kilkakrotnie w literaturze regionalnej, lecz informacje o nim są zdawkowe i mało precyzyjne, a w niektórych przypadkach nawet sprzeczne ze sobą i błędne. Przypisuje się mu choćby udział w powstaniu styczniowym czy też urząd dziekana dekanatu strzyżowskiego. S. Wnęk, Elita strzyżowska od schyłku XIX do połowy XX wieku. Wybrane zagadnienia, „Strzyżowski Rocznik Muzealny", 2 (2016) s. 210-213; M. Bober, Dekanat strzyżowski od 1807 roku. Wybrane zagadnienia, „Strzyżowski Rocznik Muzealny”, 4 (2018) s. 55.

${ }^{2}$ B. Łopuszański, Nahlik August (1812-1878), Polski Słownik Biograficzny, t. 22: Morsztyn Zbigniew-Niemirycz Teodor, red. E. Roztworowski, Wrocław-Warszawa-Kraków-Gdańsk 1977, s. 460461; Archiwum Państwowe w Przemyślu (dalej: APPm), c.k. notariusz Feliks Misky w Strzyżowie 1878-1879, sygn. 1, s. 40-45.

${ }^{3}$ Polska Akademia Nauk, Materiały do Polskiego Słownika Biograficznego, Informacje dotyczące ks. Augusta Nahlika (1812-1878), zgromadzone przez Bolesława Łopuszańskiego, Fragment fotografii z wizerunkiem księdza, II poł. XIX w.; Fotografię ks. Nahlika znaleźć można również we wspomnieniach Stanisława E. Nahlika, Przesiane przez pamięć, t. 1: W rodzinnym gnieździe, Kraków 1987, ilustr. 10.

${ }^{4}$ S.S. Nicieja, Moje Kresy. Cmentarz w Drohobyczu, https://nto.pl/moje-kresy-cmentarz-w-drohobyczu/ar/9050733 (dostęp: 20.04.2020); A. Boniecki, Herbarz polski, cz. 1: Wiadomości historyczno-genealogiczne o rodach szlacheckich, t. 5, Warszawa 1902, s. 269; J.S. Dunin-Borkowski, Rocznik szlachty polskiej, t. 1, Lwów 1881, s. 461-462; W.W. Fedorowicz, Wiadomość o Fedorowiczach, cz. 1, Lwów 1880, s. 20; Łopuszański, Nahlik August (1812-1878), s. 460; Nahlik, Przesiane przez pamięć, s. 15.
} 
Ukończywszy w 1830 r. gimnazjum we Lwowie, osiemnastoletni August wstąpił do seminarium duchownego w Przemyślu, a w 1834 r. przyjął z rąk bpa Michała Korczyńskiego święcenia kapłańskie w katedrze przemyskiej. Tego samego roku skierowany został na swoją pierwszą placówkę duszpasterską, do parafii pw. św. Mateusza w Gniewczynie koło Łańcuta (dziś Gniewczyna Łańcucka), w której proboszczem był wówczas ks. Antoni Kilian. Jednakże w następnym roku wysłany został do parafii w Żołyni, należącej do ówczesnego dekanatu leżajskiego, gdzie do $1837 \mathrm{r}$. jako jeden z dwóch wikariuszy pomagał ówczesnemu proboszczowi ks. Pawłowi Sokalskiemu w zarządzaniu, liczącą wówczas przeszło 8000 wiernych, parafią5.

Jako wikary ks. Nahlik musiał zapewne czynnie działać na rzecz parafii i wyróżniać się wśród pozostałych księży, gdyż już w trzecim roku od wyświęcenia powierzona została mu pierwsza odpowiedzialna funkcja. W 1837 r., po śmierci proboszcza zaleszańskiego, ks. Feliksa Jaworskiego, dwudziestopięcioletni wówczas wikary z Żołyni wyznaczony został na administratora tamtejszej parafii aż do czasu powołania nowego proboszcza. Administrowanie parafią nie trwało zbyt długo, bo już na początku 1838 r. proboszczem w parafii pw. św. Mikołaja Biskupa w Zaleszanach mianowany został ks. Wojciech Dziama. Księdzu Nahlikowi powierzona została zaś kolejna administracja, tym razem w należącej do dekanatu drohobyckiego parafii pw. św. Katarzyny w Rumnie, która z chwilą objęcia przez niego stanowiska administratora liczyła niespełna 700 wiernych, gdyż przeważającą większość na tych terenach stanowiła greckokatolicka ludność ukraińska. Parafią tą zarządzał do 1844 r., kiedy to w końcu zastąpił dotychczasowego jej proboszcza ks. Franciszka Nowickiego, profesora historii Kościoła i prawa kanonicznego w Diecezjalnym Instytucie Teologicznym w Przemyślu, któremu powierzono prepozyturę w Leżajsku'.

To właśnie w czasie swojego pobytu w Rumnie ks. Nahlik aktywnie zaangażował się w działalność konspiracyjną, nawiązując m.in. bliską współpracę z Edwardem Dembowskim, lewicowym działaczem niepodległościowym, członkiem tajnej organizacji Związek Narodu Polskiego, a także jednym z późniejszych organizatorów i przywódców powstania krakowskiego w 1846 r. Wkrótce też stał się jedną z czołowych postaci tzw. spisku w Horożannie, miejscowości, w której - jak pisze Stefan Dembiński - „(...) gromadzić się miała wciągnięta do ruchu młodzież uniwersytecka ze Lwowa (...)”, i która ,....) była punktem środkowym, z którym znosiła się okolica i patrioci (...)" "7.

Spisek w Horożannie, którego głównym pomysłodawcą i organizatorem był tamtejszy administrator majątku Niezabitowskich, mandatariusz Ferdynand Czaplicki, miał na celu wywołanie lokalnego powstania z udziałem chłopów, oficjalistów dworskich i szlachty zagrodowej. Wspólnie z innymi tego typu wystąpieniami na terenie

${ }^{5}$ Tamże, s. 461; Schematismus universi venerabilis cleri dioecesis ritus latini Premisliensis in annum 1835-1837, Premisliae 1835-1837; A. Motyka, Duchowni wyświęceni w tacińskiej diecezji przemyskiej w latach 1788-1834, Rzeszów 2015, s. 40.

${ }^{6}$ Schematismus universi venerabilis cleri dioecesis ritus latini Premisliensis in annum 18371844, Premisilae 1837-1844.

${ }^{7}$ S. Dembiński, Rok 1846. Kronika dworów szlacheckich zebrana na pięćdziesięcioletnia rocznicę smutnych wypadków lutego, Jasło 1896, s. 167-168. 
całej Galicji miał stać się ważnym ogniwem w przygotowywanym od lat 40. XIX wieku przez Towarzystwo Demokratyczne Polskie ogólnonarodowym zrywie przeciwko władzy zaborczej, którego plan zakładał opanowanie głównych centrów administracji austriackiej, w tym najważniejszych ośrodków Galicji Wschodniej: Brzeżan, Jarosławia, Lwowa, Przemyśla, Stanisławowa i Tarnopola ${ }^{8}$.

WażnymmiejscemdlaspiskowcówbyłarównieżparafiarzymskokatolickawRumnie, której proboszczem był już wówczas ks. Nahlik. To właśnie na tamtejszej plebanii odbywały się tajne narady zudziałemm.in. Czaplickiego, Dembowskiego i Teofila Wiśniowskiego, głównego przedstawiciela Komitetu Rewolucyjnego na Galicję Wschodnią. Tam także gromadzona była broń dla przyszłych działań zbrojnych. Aktywnie zaangażowany w spisek ks. Nahlik, wraz z wikariuszem z Drohobycza, ks. Józefem Gurakiem, mianowany został przez Wiśniowskiego agentem rewolucyjnym na teren cyrkułu samborskiego i tym samym znalazł się w gronie ścisłego kierownictwa zaplanowanego na 21 lutego 1846 r. powstania9 .

W pierwszej kolejności powstańcy z Horożanny planowali uderzyć na pobliski Sambor, następnie zająć znajdujące się w Rodatyczach i Gródku Jagiellońskim garnizony austriackie, a w dalszej kolejności opanować Sądową Wisznię i Mościska. Stamtąd mieli przypuścić atak na Przemyśl, gdzie do tego czasu dotrzeć miały już oddziały powstańcze z innych rejonów ${ }^{10}$.

Jednak na dzień przed wybuchem powstania napływające do Galicji Wschodniej wieści o niepowodzeniach i klęskach podobnych wystąpień rozpoczętych wcześniej w zachodnich cyrkułach Galicji (tarnowskim, bocheńskim, sądeckim, wielickim, jasielskim czy też sanockim), a także wrogie nastawienie do spisków samych chłopów, które za przyzwoleniem i namową władz austriackich przerodziło się tam w mające charakter antyszlachecki i antypańszczyźniany bunty chłopskie, skłoniły Wiśniowskiego do podjęcia decyzji o odwołaniu powstania. Wysłał więc on do księdza Nahlika wiadomość, aby ten udał się jak najszybciej do Horożanny i przekazał zgormadzonym tam spiskowcom rozkaz odwołania całej akcji.

Niestety, wiadomość ta dotarła do Rumna dopiero o świcie następnego dnia, na kilka godzin przed wybuchem powstania i pomimo natychmiastowego wyjazdu księdzu Nahlikowi nie udało się dostarczyć jej na czas. Gdy dotarł on przed dom Czaplickiego, ten był już ze wszystkich stron otoczony przez chłopów, którzy zatrzymali duchownego i osadzili go $\mathrm{w}$ areszcie domowym wraz $\mathrm{z}$ innymi spiskowcami przybyłymi tego poranka do Horożanny. O mającym wybuchnąć powstaniu chłopi wiedzieli już wcześniej i poinformowali o tym fakcie greckokatolickiego proboszcza w Horożannie, ks. Onufrego Horodyskiego, który zawiadomił komendę wojskową w Drohowyżu. Tam zaś duchowny otrzymał polecenie stłumienia powstania lub gdy będzie to niemożliwe - powstrzymania spiskow-

${ }^{8}$ S.S. Nicieja, M. Patelski, Rok 1846 we Lwowie. Stracenie Kapuścińskiego $i$ Wiśniowskiego i ich kult we Lwowie, w: Rok 1846 w Galicji. Ludzie, wydarzenia, tradycje. Zbiór studiów, red. M. Sliwa, Kraków 1997, s. 78.

${ }^{9}$ B. Łopuszański, Udziat księży diecezji przemyskiej w konspiracjach galicyjskich $w$ latach 18311846, „Nasza Przeszłość”, 43 (1975), s. 189-190; tenże, Nahlik August (1812-1878), s. 461; B. Limanowski, Historia ruchu rewolucyjnego w Polsce w 1846, Kraków 1913, s. 110, 178.

${ }^{10}$ Łopuszański, Udział księży diecezji przemyskiej w konspiracjach galicyjskich. 
ców, aż do czasu nadejścia posiłków wojskowych ze Lwowa. Na nic zdały się dawane ze strony Czaplickiego obietnice o ulgach podatkowych i zniesieniu pańszczyzny. Podbuntowani przez proboszcza i wójta z Horożanny Dmytra Kuchara chłopi obrócili się przeciw powstańcom i otoczyli dom mandatariusza, aby aresztować go wraz z pozostałymi spiskowcami i przekazać w ręce zbliżających się Austriaków ${ }^{11}$.

Spiskowcy postanowili jednak walczyć i zaczęli strzelać do chcących ich aresztować chłopów, a gdy ci podpalili dach domu mandatariusza, przedarli się na drugą stronę drogi do aresztu i ze znajdującymi się tam więźniami dalej stawiali zacięty opór. Część z nich widząc przeważające siły i zagrożenie życia ze strony rozwścieczonych chłopów, którzy podpalili również areszt, postanowiła się przebić i uciec lub - gdy będzie to niemożliwe - samemu poddać się Austriakom, gdyż uważali, że wpadłszy w ich ręce, mogą zostać od razu zabici. Tadeusz Zubrzycki tak opisuje dalsze zajścia w Horożannie:

Jednak masa chłopstwa rzuciła się na nich i formalnie zgniotła ich swym ciężarem. Padli na miejscu pod razami Ferdynand i Henryk Czapliccy, Tadeusz Łaszkiewicz, Józef Waligórski, Jan Bredemajer, Gracjan Łagoński i Jan Bilewicz. Reszta, zbita i pokaleczona w najokropniejszy sposób, po krótkim oporze, wpadła w ręce chłopów. Tylko dwaj z tego grona, Sikorski i Müller, usiłowali ratować się ucieczką. Gdy zobaczyli, że nie ujdą ścigającej ich thuszczy, postanowili wzajemnie śmierć sobie zadać. Padły dwa strzały - Sikorski zginął na miejscu, zaś Müller, ciężko ranny, dostał się w ręce chłopów. Późnym wieczorem przybyło wojsko ze Lwowa, lecz zastało na miejscu tylko rannych, trupy i zgliszcza. Rannych wsadzono na chłopskie wozy i pod eskortą huzarów odstawiono ich do Lwowa, gdzie w szpitalu więziennym leczeni byli starannie, by dostarczyć obfitego materiału sędziom śledczym ${ }^{12}$.

Po latach ks. Nahlik wrócił wspomnieniami do tych dni, przy okazji odpowiadając również na zarzuty formułowane pod jego adresem na łamach „Dziennika Literackiego" i „Postępu”, że wiedząc już dzień wcześniej o odwołaniu powstania, nie poinformował na czas zebranych w Horożannie spiskowców. Wyjaśniał:

Nie tego samego wieczora (20 lutego) jak autor Powieści o Horożanie, źle zainformowany fałszywie podał, ale dopiero dnia 21go lutego, o godzinie ósmej rano otrzymałem przez wysłaną od komitetu rewolucyjnego panią W. uwiadomienie o wypadkach Tarnowskich, oraz polecenie, aby zgromadzonych w Horożannie powstańców do rozjechania się natychmiast zawezwać, gdyż powstanie na teraz odwołanym zostaje. Pojmując nadzwyczajną ważność tego rozkazu, nie czekałem aż mój furman konie zaprzęże, natychmiast siadłem na sanie dopiero co przybyłej pani W. i pospieszyłem do Horożanny. Niestety, przybyłem za późno. Wójci i gromady, przedwcześnie uwiadomieni o powstaniu, chociaż wedle planu spiskowych dopiero o wpół do dziesiątej miał przybyć komisarz rewolucyjny i przeczytać zgromadzonemu ludowi proklamację i do udziału zawezwać - ściągnęli przez urlopników z pobliższych wiosek

${ }^{11}$ S. Kieniewicz, Ruch chłopski w Galicji w 1846 roku, Wrocław 1951, s. 169-170; S. Schnürr -Pepłowski, Z przeszłości Galicji (1772-1862), Lwów 1895, s. 442-444; T. Zubrzycki, Rzeź galicyjska wr. 1846, Stanisławów 1910, s. 20-21.

${ }^{12}$ Tamże, s. 22. 
kilka tysięcy włościaństwa, uzbrojonego w kosy, cepy, pałki, a nawet i w strzelby, i trzymali już od kilku godzin przed moim przybyciem związkowych w oblężeniu w domu Czaplickiego. Nikogo nie dopuszczali do nich, a wszystkich później przybywających aresztowali natychmiast i osadzali w areszcie dominikalnym, po drugiej stronie drogi stojącym. Taki los spotkał i mnie, i z tej przyczyny nie mogłem się porozumieć z oblężonymi i zdać sprawę z posłannictwa mego ${ }^{13}$.

Spisek w Horożannie był jednym z największych i najlepiej przygotowanych spisków we wschodniej Galicji, który - gdyby nie negatywne nastawienie warstwy chłopskiej i wcześniejsze zdekonspirowanie - miałby duże szanse powodzenia. Według Zubrzyckiego Horożanna obok Narajowa to także miejsce najkrwawszych zajść, do jakich doszło w tej część Galicji, które ze stłumienia spisku przez chłopów przerodziły się w pogrom jego członków, który zaliczyć można do wydarzeń, do jakich doszło w tym samym czasie w Galicji Zachodniej, określanych później mianem „rzezi galicyjskiej”"14. Z kolei Stefan Kieniewicz uważa zupełnie co innego. „W przeciwieństwie do Galicji Zachodniej - pisze Kieniewicz - powstańcy horożańscy polegli w otwartej walce i trudno kłaść ich zgubę na karb jakiegoś szczególnego okrucieństwa chłopów”, a dalej: „(...) sama więc Horożanna służy jako sprawdzian, że lud ukraiński w tych stronach odniósł się do powstania zdecydowanie wrogo"15.

Niemniej jednak dzięki ogromnemu szczęściu i licznym zbiegom okoliczności ks. Nahlikowi udało się ujść z życiem i uniknąć losu, jaki spotykał innych spiskowców, którzy zginęli od kos i cepów zbuntowanych chłopów, albo widząc nieubłaganą klęskę wywołanego powstania, woleli popełnić samobójstwo.

Szczęście to nie trwało jednak zbyt długo, gdyż po kilkumiesięcznym, wyczerpującym śledztwie ks. Nahlik oskarżony został w końcu o zdradę stanu i skazany 26 listopada 1846 r. na 12 lat więzienia ${ }^{16}$. Wyrok ten nie zyskał aprobaty władzy zaborczej, która uważała, że pozostający przy życiu jeden z ostatnich przywódców spisku w Horożannie zasługuje na dużo wyższą karę i złożyła od niego apelację. Rozpatrujący ją sąd przyznał zaborcom rację i skazał duchownego na dożywocie. W kolejnym roku kara ta uległa zmianie i dekretem Ministerstwa Sprawiedliwości z dnia 4 kwietnia zamieniono ją na 15 lat pobytu w jednym z najcięższych więzień monarchii austriackiej, znajdującym się w twierdzy Spielberg, do którego trzydziestopięcioletni wówczas ks. Nahlik trafił 8 lipca 1847 r. wraz z m.in. Maksymilianem Müllerem, innym spiskowcem z Horożanny ${ }^{17}$.

Wyczerpujące śledztwo i dotychczasowy pobyt w więzieniu w znaczący sposób odbiły się na zdrowiu ks. Nahlika, sprawiając, że gdy trafił on do Spielbergu,

${ }^{13}$ F.W. Czaplicki, Rzeź w Horożanie i Pamiętnik więźnia stanu. Dwa dzieła w jednym tomie, Kraków 1872, s. 96.

${ }^{14}$ Zubrzycki, Rzeź galicyjska wr. 1846, s. 20.

${ }^{15}$ Kieniewicz, Ruch chtopski w Galicji w 1846 roku, s. 170.

${ }^{16}$ Lopuszański, Nahlik August (1812-1878), s. 361.

${ }^{17}$ Tamże; Biblioteka Zakładu Narodowego im. Ossolińskich we Wrocławiu, Dział Rękopisów, Rok 1846. Relacje współczesne i listy naocznych świadków dotyczące rabacji galicyjskiej, sygn. 5791/II, s. 28. 
był w bardzo złej kondycji fizycznej. Zauważył to przybyły tam kilka dni wcześniej brat Czaplickiego, Franciszek Władysław, skazany na 10 lat więzienia również za udział w spisku. Zanotował on później w swoim pamiętniku:

Ksiądz Nahlik z natury już bardzo delikatnej kompleksji, był nadto wówczas słaby; przykro było się patrzyć na niego, wycieńczonego jakkolwiek tylko na fizycznych siłach, a zakutego w ciężkie kajdany ${ }^{18}$.

Niebawem los uśmiechnął się do ks. Nahlika po raz kolejny, w wyniku bowiem konsekwencji, jakie pociągnęła za sobą w Cesarstwie Austrii przetaczająca się przez Europę Wiosna Ludów, został objęty amnestią i 23 marca 1848 r. zwolniony z więzienia. W końcu też mógł powrócić do Galicji. Jednakże w oczach władzy nadal stanowił zagrożenie, dlatego też wymogła ona na konsystorzu nałożenie na duchownego suspensy zakazującej sprawowania sakramentów (łącznie z mszą świętą) i pełnienia funkcji kościelnych. Nie pozwolono mu również powrócić do swojej starej parafii w Rumnie. Do sił i zdrowia dochodził w dobrach birczańskich należących do siostry Marii Ludwiki (1814-1873) i jej męża Adama Anzelma Wojciecha Kowalskiego h. Abdank (1795-1866), w których - po śmierci ojca - przebywała również jego matka ${ }^{19}$.

Prawie roczny pobyt w Birczy miał być dla ks. Nahlika także swego rodzaju rekolekcjami, które pod nadzorem władzy, zarówno duchownej, jak i rządowej, doprowadzić miały w nim do skruchy i zmiany sposobu myślenia, a także do trwałej poprawy poglądów politycznych, tak jak to miało miejsce w przypadku zaangażowanych w spisek niepodległościowy księży z diecezji tarnowskiej ${ }^{20}$. Przechodzili oni bowiem swoją przemianę głównie w klasztorach: bernardynów (Tarnów), cystersów (Szczyrzyc) i reformatów (Zakliczyn nad Dunajcem), gdzie przełożeni oceniali ich przemianę $\mathrm{i}$,informowali biskupa o każdym ważniejszym wydarzeniu związanym z internowanymi księżmi"’21.

Dostrzegając zapewne właśnie taką skruchę i poprawę w sposobie myślenia, być może także na prośbę samego ks. Nahlika, władze kościelne postanowiły w 1849 r. zdjąć ciążącą nań suspensę, umożliwiając mu tym samym powrót do pracy duszpasterskiej i sprawowania sakramentów. Powodu tak szybkiego przywrócenia duchownego do jego obowiązków można dopatrywać się również w problemie, z jakim borykał się wówczas Kościół katolicki nie tylko na terenach Galicji, lecz także w pozostałych zaborach, a który związany był bezpośrednio z brakiem dostatecznej liczby księży ${ }^{22}$. Niemniej jednak, jak pisze Stanisław E. Nahik, „karie-

${ }^{18}$ Czaplicki, Rzeź w Horożanie i Pamiętnik więźnia stanu, s. 182.

${ }^{19}$ Lopuszański, Nahlik August (1812-1878), s. 361; J. Radimsky, Wykaz polskich więźniów politycznych w Szpilbergu 1839-1848, „Sobótka”, 6 (1951) s. 181, nr 79.

${ }^{20}$ Jak obliczył ks. Krzysztof Kamieński w diecezji tarnowskiej za udział w spisku niepodległościowym z $1846 \mathrm{r}$. lub za podejrzenie udziału w nim różnego rodzaju represjom poddanych zostało 8\% ogółu całego duchowieństwa, głównie z cyrkułów tarnowskiego (20\%) i bocheńskiego (17\%). Niestety brak takich danych odnośnie do diecezji przemyskiej. K. Kamieński, ,, Okropne dzieje przynióst nam czas". Duchowieństwo diecezji tarnowskiej wobec wydarzeń 1846 roku, Tarnów 2015, s. 86-97.

${ }^{21}$ Tamże, s. 91.

${ }^{22}$ Łopuszański, Nahlik August (1812-1878), s. 361. 
ry duchownej już potem nie zrobił, snadź lojalistyczne władze kościelne miały mu za złe owe rewolucyjne poczynania"23.

Od razu ks. Nahlika skierowano na nowe probostwo, tym razem do leżącej w dekanacie samborskim parafii pw. św. Wawrzyńca w Chyrowie, gdzie oprócz posługi duszpasterskiej zajął się modernizacją tamtejszej świątyni. W trakcie prowadzonych w 1859 r. prac remontowych odnowione zostały dwa ołtarze boczne (pw. Matki Boskiej i św. Józefa), ambona oraz prospekt organowy. Wystawiony został również nowy ołtarz główny ${ }^{24}$.

Dwa lata wcześniej ks. Nahlikowi udało się zakupić także w Pradze obraz pędzla Gustawa Poppe z wizerunkiem św. Wawrzyńca, który następnie umieszczony został w chyrowskiej świątyni. Stało się to wszystko możliwe dzięki wsparciu Edwarda Pleschnera, prezesa Praskiego Zarządu Handlu i założyciela Wyższej Szkoły Handlowej w Pradze, który w całości sfinansował zakup obrazu. Na łamach lwowskiego „Przyjaciela Domowego” i krakowskiego „Czasu”, chyrowski proboszcz dziękował fundatorowi, który - jak pisał w przesłanych do redakcji listów:

(...) nie znając ani mnie, ani mój kościół, poruszony jedynie dobrą chęcią moją i niemożnością dopięcia zamierzonego prze mnie zamysłu, dobrowolnie podjął się ponieść wszelkie i znaczne koszta przy zakupieniu rzeczonego obrazu z własnych funduszów

i dalej, że

pamięć tego poświecenia przejdzie w późne wieki wraz z arcydziełem czeskiego artysty, które jako krzew trwały przeniesiony ze ziemi czeskiej na niwy pobratymczej Polski, wdziękiem i krasą swoją nieprzestanie przypominać życzliwych nam braci i szlachetnego fundatora obrazu ${ }^{25}$.

Parafią w Chyrowie ks. Nahlik zarządzał do 1864 r., kiedy to wskutek zmian dokonanych przez biskupa przemyskiego Antoniego Manastyrskiego, przeniesiony został do parafii pw. Niepokalanego Poczęcia NMP i Bożego Ciała w Strzyżowie. Zastąpił tam skłóconego z miejscowym kolatorem, dotychczasowego proboszcza, ks. Józefa Twaroga (1816-1886), który od 1844 r. zarządzał parafią, i który to - notabene - zastąpił go na probostwie w Chyrowie ${ }^{26}$.

Licząca ponad 5000 wiernych parafia w Strzyżowie była ostatnią placówką duszpasterską ks. Nahlika. W niej to spędził resztę życia, kontynuując dzieło zapoczątkowane przez swojego poprzednika, mające na celu doprowadzenie do odrodzenia życia religijnego w parafii, a także przywrócenie dawnej świetności zdewa-

${ }^{23}$ Nahlik, Przesiane przez pamięć, s. 20.

${ }^{24}$ Lopuszański, Nahlik August (1812-1878), s. 361; J. K. Ostrowski, Kościót parafialny p.w. św. Wawrzyńca w Chyrowie, w: Materiaty do dziejów sztuki sakralnej na ziemiach wschodnich dawnej Rzeczypospolitej, red. J. K. Ostrowski, cz. 1, Kościoły i klasztory rzymskokatolickie dawnego województwa ruskiego, t. 5, Kraków 1997, s. 32-33.

${ }^{25}$ Tamże; „Przyjaciel Domowy”, 1857, nr 44, s. 370; „Czas”, 10 (1857), nr 216, s. 4.

${ }^{26}$ Lopuszański, Nahlik August (1812-1878), s. 361; Schematismus universi venerabilis cleri dioecesis ritus latini Premisliensis in annum 1849-1866, Premisliae 1849-1866. Nagrobek ks. Józefa Twaroga (1816-1886) znajdujący się na cmentarzu komunalnym w Chyrowie, http://www.nieobecni.com.pl/index.php?s=grob\&id=177463 (dostęp: 22.04.2020). 
stowanej w czasach józefińskich świątyni, którą -jak pisał w liście do Antoniego Schneidera - dzięki własnym zabiegom odbudowa ${ }^{27}$.

To właśnie dzięki staraniom nowego proboszcza zbudowany został w lewej nawie bocznej kościoła w Strzyżowie ołtarz Matki Bożej Różańcowej, a także dokonano konsekracji nowej kaplicy pw. św. Michała Archanioła, ufundowanej w 1863 r. przez Konstancję Dydyńską, ku pamięci Antoniego Dydyńskiego z Godowej $^{28}$. Również sam ks. Nahlik sfinansował w 1866 r., znajdującą się obecnie po prawej stronie prezbiterium, tablicę inskrypcyjną ku czci ks. Adama Augustinusa, proboszcza strzyżowskiego w latach $1597-1636$, pierwszego prepozyta kolegiaty strzyżowskiej i pierwszego dziekana dekanatu strzyżowskiego ${ }^{29}$.

Ksiądz Nahlik żywo zainteresowany był również przeszłością strzyżowskiej parafii. W liście do Antoniego Schneidera zachęcał go do ustalenia najważniejszych faktów dotyczących strzyżowskiego kościoła i odszukania materiałów źródłowych, które by go dotyczyły, w tym najważniejszego aktu fundacyjnego kościoła oraz erygującego parafię w Strzyżowie. Bo jak pisał:

Archiwum Kościelne parafii Strzyżowa pozbawione jest zupełnie choćby i najmniejszych wskazówek i śladów erekcji probostwa, fundacji kościoła i tym podobnych dat, a to z tej przyczyny, że miasto i kościół przez napady najezdnicze po wielekroć zburzone i zniszczone zostały ${ }^{30}$.

Warto wspomnieć także o dobrych stosunkach, jakie panowały między ówczesnym proboszczem strzyżowskim a licznie zamieszkującymi miasteczko Żydami ${ }^{31}$. Świadczyć może o tym chociażby, sporządzona w kancelarii c.k. notariusza Konstantego Rogalskiego, deklaracja z 7 września 1873 r., w której to ks. Nahlik zgadza się, aby w zachodniej ścianie sąsiadującego z placem plebańskim domu Żyda Salomona Wachlera, wybite zostało okno, które wychodziłoby na ten plac. Obwarowany przez proboszcza licznymi warunkami, co do wyglądu okna, sposobu jego użytkowania i zachowania się jego właścicieli podczas świąt religij-

${ }^{27}$ Archiwum Narodowe w Krakowie (ANK), sygn. TSchn 1534, Strzyżów miasto, s. 179; L. Grzebień, Zarys dziejów parafii w Strzyżowie, ,Strzyżowski Rocznik Muzealny”, 3 (2017) s. 143.

${ }^{28}$ Antoni Dydyński (1732-1808), właściciel Godowej, szambelan na dworze króla Stanisława Augusta Poniatowskiego (1786), komornik pilźnieński (1788), żonaty z Konstancją Rosnowską, chorążanką czerwonogrodzką, z którą nie miał potomstwa. Założyciel Funduszu na rzecz Ubogiej Młodzieży (1808), który wszedł w życie dopiero w latach 60. XIX wieku po przekształceniu w Fundację Stypendialną im. Antoniego Dydyńskiego, wydającą od tego czasu rok rocznie, aż do 1939 r., od kilku do kilkunastu stypendiów wspierających kształcącą się młodzież z ubogich rodzin szlacheckich. Szerzej na temat Fundacji Stypendialnej im. A. Dydyńskiego W. Ziobro, Zapis Antoniego Dydyńskiego z 2 lutego 1808 r. - przyczynek do badań nad Fundacją stypendialna im. Antoniego Dydyńskiego w Godowej, „Prace Historyczne”, 46 (2019), z. 4, s. 837-857.

${ }^{29}$ Z. Harasimowicz, B. Patryn, Epitafium Adama Augustinusa, proboszcza w Strzyżowie w latach 1597-1636, „Strzyżowski Rocznik Muzealny”, 3 (2017) s. 63-67.

${ }^{30}$ ANK, sygn. TSchn 1534, Strzyżów miasto, s. 178.

${ }^{31}$ Schematyzmy z tego okresu podają, że strzyżowski okręg parafialny, głównie miasteczko Strzyżów, zamieszkiwało wówczas ponad 2 tys. osób wyznania mojżeszowego, co stanowiło blisko 30\% całej ludności okręgu, a także prawie połowę wszystkich Żydów, zamieszkujących wtedy miejscowości tworzące dekanat strzyżowski. Schematismus universi venerabilis cleri dioecesis ritus latini Premisliensis in annum 1865-1878, Premisliae1866-1879. 
nych dokument rzuca światło na panujące wtedy relacje pomiędzy katolikami a społecznością żydowską ${ }^{32}$.

Ksiądz Nahlik dbał nie tyle o dobre relacje z wyznawcami religii mojżeszowej i poprawienie bytu materialnego mieszkańców swojej parafii, co przede wszystkim o duchowy i moralny rozwój wiernych, wspierając utworzone przez swoich poprzedników bractwa kościelne, a także tworząc dwa nowe: Bractwo Wstrzemięźliwości i działające od 1873 r. Bractwo Najświętszego Serca Pana Jezusa. Zainicjował również utworzenie katolickiej szkoły dla dziewcząt, działającej w latach 1871-1875, a po jej zamknięciu przez władze planował utworzenie ochronki dla dzieci - starania te przerwała jednak jego śmierć w 1878 r. Pomysł kontynuowali i wcielili w życie jego następcy, doprowadzając ostatecznie do otwarcia w 1912 r. prowadzonej przez siostry serafitki z Oświęcimia ochronki dla dzieci $^{33}$.

Ksiądz Nahlik zmarł na raka 15 grudnia 1878 r. w wieku 66 lat, po 14 latach posługi duszpasterskiej w parafii Niepokalanego Poczęcia NMP i Bożego Ciała w Strzyżowie, o czym poinformowały „Wiadomości Kościelne” w swoim ostatnim numerze z $1878 \mathrm{r}$. Jego pogrzeb odbył się dwa dni później, 17 grudnia $1878 \mathrm{r}^{34}$

$\mathrm{Na}$ dwa miesiące przed swoją śmiercią, 10 października 1878 r., ks. Nahlik sporządził w nowo otwartej kancelarii notarialnej Feliksa Misky'ego ${ }^{35}$ w Strzyżowie akt swojej ostatniej woli. W dniu śmierci testament ten dostarczony został przez notariusza do Sądu Powiatowego w Strzyżowie, gdzie został oficjalnie rozpieczętowany i upubliczniony, a jego wierzytelna kopia wciągnięta została do akt postępowania spadkowego. Oryginał testamentu wraz ze sporządzonym przy okazji jego spisywania protokołem, a także kopertą, w którą był zapakowany, zachował się w aktach c.k. notariusza Feliksa Misky’ego w Archiwum Państwowym w Przemyślu, gdzie wraz z pozostałymi aktami notarialnymi trafił w 1957 r. z Sądu Powiatowego w Rzeszowie ${ }^{36}$.

W liczącym niespełna trzy strony testamencie jedynym spadkobiercą posiadanego przez siebie majątku ks. August Nahlik ustanowił swojego młodszego brata, Franciszka (1817-1881). Oprócz ustanowienia spadkobiercy w ostatniej woli strzyżowskiego proboszcza znaleźć można również informacje rzucające światło na sposób zarządzania przez niego majątkiem parafii, a także opis ceremonii pogrzebowych, jakie mają się odbyć po jego śmierci. W znaczący sposób podnosi to walor źródłowy tego dokumentu i sprawia, iż może być on wykorzystany nie tylko w studiach nad XIX-wieczną historią parafii, lecz także w badaniach nad funkcjonowaniem tej spe-

${ }^{32}$ APPm, c.k. notariusz Konstanty Rogalski w Strzyżowie 1873-1874, sygn. 1, s. 57-59.
${ }^{33}$ Grzebień, Zarys dziejów parafii w Strzyżowie, s. 160-166.
${ }^{34}$ „Wiadomości Kościelne”, 6 (1878), nr 26, s. 210; APS, Strzyżów Liber Mortuorum 1868-1888 Tom III, sygn. 37, s. 28, $\mathrm{nr} 22$.

${ }^{35}$ Feliks Misky (1820-1904), notariusz strzyżowski w latach 1878-1881, żonaty z Józefą z Wierzchleyskich, której stryjem był arcybiskup Franciszek Wierzchleyski (1803-1884), w latach 1860-1884 metropolita lwowski.

${ }^{36}$ APPm, c.k. notariusz Feliks Misky w Strzyżowie 1878-1879, sygn. 1, s. 40-42; APPm, Inwentarz. Akta notariuszy miasta Strzyżowa - grupa zespołów z lat 1873-1947, oprac. A. K. Mielnik, Przemyśl 1990 (maszynopis), s. 4. 
cyficznej i zróżnicowanej pod wieloma względami grupy społecznej, jaką stanowiło w tym czasie duchowieństwo ${ }^{37}$.

\section{ANEKS}

\section{Ksiądz August Nahlik, II pol. XIX w.}

Źródło: Polska Akademia Nauk, Materiały do Polskiego Słownika Biograficznego, Informacje dotyczące ks. Augusta Nahlika (1812-1878), zgromadzone przez Bolesława Łopuszańskiego, Fragment fotografii z wizerunkiem księdza, II poł. XIX w. ${ }^{38}$

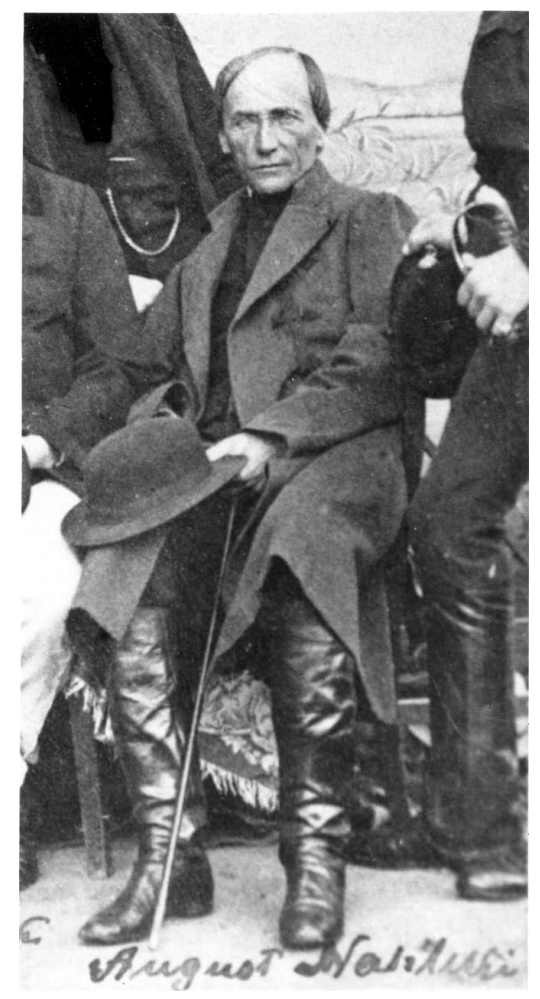

${ }^{37}$ APPm, c.k. notariusz Feliks Misky w Strzyżowie 1878-1879, sygn. 1, s. 43-44.

${ }^{38}$ Fotografię ks. A. Nahlika znaleźć można również we wspomnieniach Stanisława E. Nahlika, który tak opisuje duchownego: „suchy starzec, mocno łysawy, o regularnych rysach i bardzo jasnych, głęboko osadzonych oczach, o surowym, zaciętym wyrazie twarzy, z tęgą lagą i w wysokich butach, jakby bardziej do myślistwa lub do wojaczki powołany niż do służby bożej”. Tenże, Przesiane przez pamięć, t. 1: W rodzinnym gnieździe, Kraków 1987, s. 19, ilustr. 10. 


\section{Testament ks. Augusta Nahlika z 10 października 1878 r. $^{39}$}

Źródło: Archiwum Państwowe w Przemyślu, c.k. notariusz Feliks Misky w Strzyżowie 1878-1879, sygn. 1, s. 43-45.

[s. 43]

W imię Ojca i Syna i Ducha Św. Chwała i cześć Bogu w Trójcy jedynemu.

Ostatnia wola moja.

Ciało i duszę moją, polecam nieograniczonemu miłosierdziu Bożemu. Nie sądź mnie Boże według nieprawości moich, ale według litości Twojej, która nie żąda potępienia, ale zbawienia dusz ludzkich. Wielkie są nieprawości moje, ale zasługi Zbawiciela mojego są bez granic. Dlatego mam nadzieję, że sługę Twego mój Jezu nie opuścisz, nie dasz na zhańbienia w ostatniej chwili żywota jego, wszak całe życie pokładałem ufność i nadzieję moją w Tobie. Najświętsza Panno Maryjo módl się za mnie, gdyż Tobie Trójca Święta nic odmówić nie może.

Cały zaś ruchomy i nieruchomy majątek, jaki przy śmierci posiadam, i po śmierci na mnie spaść może, w całości bez wszelkiego wyjątku daruję i zapisuję na wyłączną własność bratu mojemu Kochanemu Franciszkowi Nahlikowi ${ }^{40}$ majorowi w pensji będącemu, którego uniwersalnym sukcesorem całego mego majątku niniejszym ustanawiam.

1. Dla informacji temuż memu sukcesorowi zostawiam następujące uwagi spisane:Do mojej pozostałości nikt żadnej pretensji mieć nie może, bo za życia zabezpieczyłem wszelkie należytości inwentarialne, tak Kościelne jako też fundus instructus ${ }^{41}$. Pieniądze za ten fundus instructus są złożone w Najprzewielebniejszym Konsystorzu, należy się jedynie oddać w naturze na inwentarz dwa wozy, jeden okuty, drugi bosy, które się znajdują w stodole folwarku plebańskiego w Strzyżowie. Trzeci wóz tamże się znajdujący całkiem nowy, moją własnością będący należy do spadkobiercy. Zasiewy zaś tak ozime jako i wiosenne [s. 44] odebrał Wielmożny Pan Ignacy Skrzyński², dzierżawca folwarku plebańskiego w Strzyżowie. A zatem rząd żadnej pretensji do masy pozostałej mieć nie może. Podatki zawsze opłacałem kwartalnie z dołu. Jeżeliby jaka okazała się zaległość, to tę należy zapłacić nie z masy, lecz ze zaległych

${ }^{39}$ Testament ks. Nahlika opracowany został z uwzględnieniem wskazówek zawartych w instrukcji wydawniczej dla źródeł z przełomu XIX i XX wieku: J. Tandecki, K. Kopiński, Edytorstwo źródet historycznych, Warszawa 2014.

${ }^{40}$ Franciszek Nahlik (1817-1881), syn Karola (1773-1834) i Karoliny Losy de Losenau (17821858), major ułanów armii austriackiej.

${ }^{41}$ Fundus instructus (łac.) - inwentarz gruntowy (miejscowy), żelazny.

${ }^{42}$ Ignacy Skrzyński h. Zaremba (1807-1895), syn Wincentego z Konstancji z Fredrów, ożeniony z Marią ze Skrzyńskich, oficer wojsk polskich w 1831 r., a także poseł do parlamentu austriackiego w 1848 r. i Sejmu Krajowego Galicji I kadencji. Właściciel dominium Strzyżów, w skład którego wchodziło: miasteczko Strzyżów i sześć wsi: Brzeżanka, Gbiska, Grodzisko, Łętownia, Przedmieście Strzyżowskie i Tropie. Ponadto w jego posiadaniu znajdowały się również dobra Harta z Lipnikiem i Paprociem, oraz wieś Glinik Charzewski i część wsi Godowa zwana „Szpitalną”. W latach 1861-1884 sprawował także urząd kuratora w Fundacji Stypendialnej im. Antoniego Dydyńskiego w Godowej. 
a mnie przypadających rent i odsetków od obligacji kościelnych - reszta z tych rent wpłynie do masy na rzecz brata mego.

2. Długów żadnych nie mam. Należytość dzierżawną z gruntów plebańskich pobierałem tak od Wielmożnego Pana Skrzyńskiego, dzierżawcy folwarku plebańskiego w Strzyżowie, jako też od Pana Berglasa ${ }^{43}$ z Glinika, dzierżawcy folwarku w Zaborowiu, w ratach miesięcznych z góry. Pretensje wypływające z nadpłaconego lub niedopłaconego czynszu obliczy spadkobierca w porozumieniu z Księdzem Dziekanem ${ }^{44}$. Sługom kościelnym i sługom domowym wypłacałem ich należytość każdego miesiąca bez zaległości z dołu.

3. Życzeniem moim jest, aby po śmierci ciało moje w średnim pokoju przed kaplicą umieszczone było. Do ubrania mam moje własne aparata ${ }^{45}$. Na trumnę i światło złożone są pieniądze w kasie zaliczkowej w Strzyżowie. Trzydzieści dwie świece $1 \mathrm{złr}$. do katafalku a 40 świec 1/4 złr. do rąk. Upraszam, aby ani kościelnego, ani cechowego nie używać światła. Chorągwi tylko 2 brackich z Różańca. Życzeniem moim jest, aby ludzie ze wsi ciało moje nieśli do kościoła i na cmentarz.

Uczyniwszy takie rozporządzenie mej ostatniej woli upraszam gorąco o przebaczenie tych wszystkich, którzy mają do mnie urazę - nawzajem i ja darowuję z serca wszelkie uchybienia mnie wyrządzone.

Na koniec żegnam moich parafian, księży, znajomych, braci, siostry, krewnych i proszę modlić się do Boga, aby raczył mnie łaskawie sądzić i umieścić w chwale Swojej.

Wierzytelne odpisy tego testamentu znajdują się [s. 45] jeden u Wielebnego Księdza Dziekana, drugi u brata mego Franciszka Nahlika, a oryginał u c.k. Notariusza w Strzyżowie jest deponowany.

Strzyżów, dnia 10 października 1878.

Jako świadek ostatniej woli

Apolinary Dydyński ${ }^{46}$

Jako świadek ostatniej woli

ks. Wincenty Łukaszkiewicz ${ }^{47}$

Jako świadkowie ostatniej woli

ks. Michał Puchalik ${ }^{48}$

${ }^{43}$ Mendel Berglas, właściciel dóbr tabularnych w Gliniku Charzewskim w ówczesnym obwodzie rzeszowskim.

${ }^{44}$ W latach 1864-1887 dziekanem dekanatu strzyżowskiego był ks. Feliks Buchwald (1819-1887) proboszcz parafii pw. św. Stanisława Biskupa i Męczennika w Dobrzechowie.

${ }^{45}$ Aparata od łac. aparatta, oznaczającego rzeczy osobiste.

${ }^{46}$ Apolinary Piotr Innocenty Dydyński (1819-1881), syn Michała Marcina Klemensa i Rozalii z Jarosiewiczów, żonaty z Sybillą z Pieściorowskich, córką Marcina i Józefy z Nowosieleckich. W latach 1875-1881 administrator Fundacji Stypendialnej im. Antoniego Dydyńskiego w Godowej.

${ }^{47}$ Ks. Wincenty Łukaszkiewicz (1846-1888), wikariusz parafii strzyżowskiej w latach 1874-1879, do której przeniesiony został z parafii w Tarnowcu. Po śmierci ks. Nahlika mianowany został administratorem parafii Strzyżów, a po mianowaniu nowego proboszcza przeniesiony został na parafię w Zręcinie, w 1882 r. zaś mianowany najpierw administratorem a następnie proboszczem w parafii Bóbrka w ówczesnym dekanacie żmigrodzkim.

${ }^{48}$ Ks. Michał Puchalik (1854-1931), wikariusz parafii strzyżowskiej w latach 1878-1882, do której trafił zaraz po święceniach. W 1881 r. przeniesiony został na parafię w Błażowej, a następnie do parafii: 

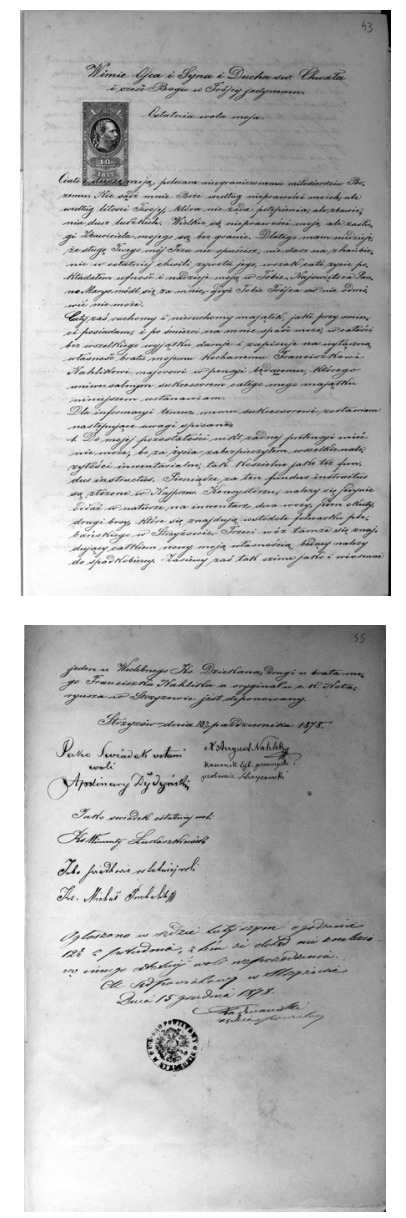

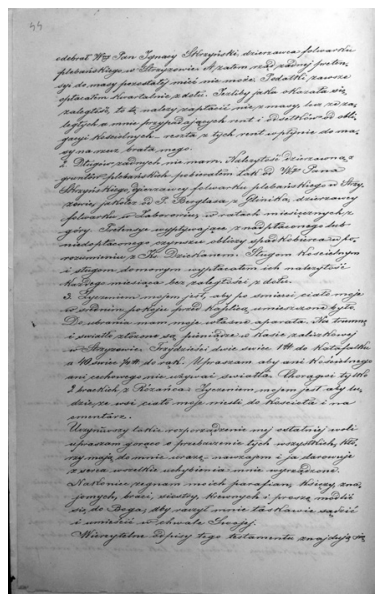

3. Koperta, w której przechowywany byl testament

Źródlo: Archiwum Państwowe w Przemyślu, c.k. notariusz Feliks Misky w Strzyżowie 1878-1879, sygn. 1, s. 42.

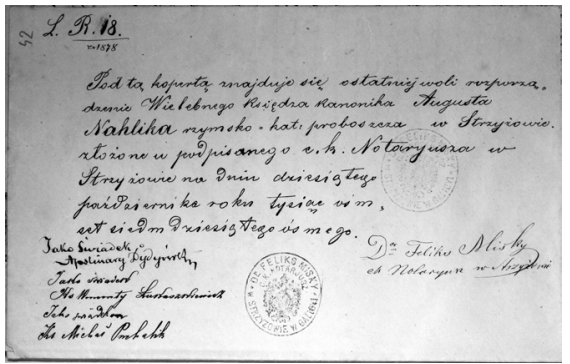

\section{Metryka zgonu ks. Augusta Nahlika (15 grudnia 1878)}

Źródło: Archiwum Parafii Strzyżów, Strzyżów Liber Mortuorum 1868-1888 Tom III, sygn. 37, s. $28, \mathrm{nr} 22$.

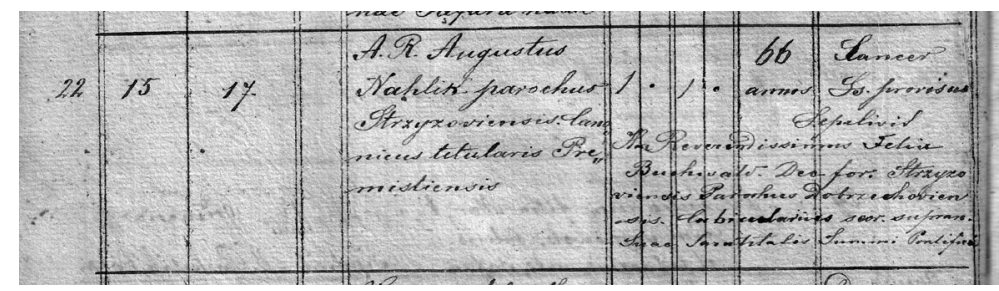

Stany, Trześń, Miechocin, Uherce i Lesko, skąd w 1892 r. trafił do Szerzyn, w ówczesnym dekanacie Brzostek, gdzie mianowany został proboszczem tamtejszej parafii. 


\section{REFERENCES / BIBLIOGRAFIA}

\section{Źródla rękopiśmienne}

Archiwum Parafii Strzyżów

Strzyżów Liber Mortuorum 1868-1888 Tom III, sygn. 37, s. 28, nr 22.

Archiwum Narodowe w Krakowie

Strzyżów miasto, sygn. TSchn 1534, s. 178-180.

Archiwum Państwowe w Przemyślu

Inwentarz. Akta notariuszy miasta Strzyżowa - grupa zespołów z lat 1873-1947, oprac.

A.K. Mielnik, Przemyśl 1990 (maszynopis).

c.k. notariusz Feliks Misky w Strzyżowie 1878-1879, sygn. 1, s. 40-45.

c.k. notariusz Konstanty Rogalski w Strzyżowie 1873-1874, sygn. 1, s. 57-59.

Biblioteka Zakładu Narodowego im. Ossolińskich we Wrocławiu, Dział Rękopisów

Rok 1846. Relacje współczesne i listy naocznych świadków dotyczące rabacji galicyjskiej, sygn. 5791/II.

Polska Akademia Nauk

Materiały do Polskiego Słownika Biograficznego, Informacje dotyczące ks. Augusta Nahlika (1812-1878), zgromadzone przez Bolesława Łopuszańskiego, Fragment fotografii z wizerunkiem księdza, II poł. XIX w.

\section{Źródła drukowane}

Czaplicki Ferdynand W., „Rzeź w Horożanie” i „Pamiętnik więźnia stanu”. Dwa dzieła w jednym tomie, Kraków 1872.

Nahlik Stanisław E., Przesiane przez pamięć, t. 1: W rodzinnym gnieździe, Kraków 1987.

Schematismus universi venerabilis cleri dioecesis ritus latini Premisliensis in annum 18371879, Premisliae 1835-1879.

\section{Prasa}

„Czas”, 10 (1857), nr 216.

„Przyjaciel Domowy”, 1857, nr 44

„Wiadomości Kościelne”, 6 (1878), nr 26.

\section{Opracowania}

Boniecki Adam, Herbarz polski, cz. 1: Wiadomości historyczno-genealogiczne o rodach szlacheckich, t. 5, Warszawa 1902.

Bober Monika, Dekanat strzyżowski od 1807 roku. Wybrane zagadnienia, „Strzyżowski Rocznik Muzealny", 4 (2018) s. 48-63.

Dembiński Stefan, Rok 1846. Kronika dworów szlacheckich zebrana na pięćdziesięcioletnia rocznicę smutnych wypadków lutego, Jasło 1896.

Dunin-Borkowski Jerzy S., Rocznik szlachty polskiej, t. 1, Lwów 1881.

Fedorowicz Władysław W., Wiadomość o Fedorowiczach, cz. 1, Lwów 1880.

Grzebień Ludwik, Zarys dziejów parafii w Strzyżowie, „Strzyżowski Rocznik Muzealny”, 3 (2017) s. 131-170.

Harasimowicz Zofia, Patryn Bogdan, Epitafium Adama Augustinusa, proboszcza w Strzyżowie w latach 1597-1636, „Strzyżowski Rocznik Muzealny”, 3 (2017) s. 63-67.

Kamieński Krzysztof, „, Okropne dzieje przynióst nam czas”. Duchowieństwo diecezji tarnowskiej wobec wydarzeń 1846 roku, Tarnów 2015.

Kieniewicz Stefan, Ruch chłopski w Galicji w 1846 roku, Wrocław 1951. 
Limanowski Bolesław, Historia ruchu rewolucyjnego w Polsce w 1846, Kraków 1913.

Łopuszański Bolesław, Udziat księży diecezji przemyskiej w konspiracjach galicyjskich w latach 1831-1846, „Nasza Przeszłość”, 43 (1975) s. 171-199.

Łopuszański Bolesław, Nahlik August (1812-1878), Polski Słownik Biograficzny, t. 22: Morsztyn Zbigniew-Niemirycz Teodor, red. E. Roztworowski, Wrocław-Warszawa -Kraków-Gdańsk 1977, s. 460-461.

Motyka Andrzej, Duchowni wyświęceni w tacińskiej diecezji przemyskiej w latach 1788 1834, Rzeszów 2015.

Nicieja Stanisław S., Patelski Mariusz, Rok 1846 we Lwowie. Stracenie Kapuścińskiego $i$ Wiśniowskiego i ich kult we Lwowie, w: Rok 1846 w Galicji. Ludzie, wydarzenia, tradycje. Zbiór studiów, red. M. Śliwa, Kraków 1997, s. 77-100.

Ostrowski Jan K., Kościót parafialny p.w. św. Wawrzyńca w Chyrowie, w: Materiały do dziejów sztuki sakralnej na ziemiach wschodnich dawnej Rzeczypospolitej, red. J. K. Ostrowski, cz. 1, Kościoły i klasztory rzymskokatolickie dawnego województwa ruskiego, t. 5, Kraków 1997, s. 30-40.

Radimsky Jerzy, Wykaz polskich więźniów politycznych w Szpilbergu 1839-1848, „Sobótka”, 6 (1951) s. 173-188.

Schnürr-Pepłowski Stanisław, Z przeszłości Galicji (1772-1862), Lwów 1895.

Tandecki Janusz, Kopiński Krzysztof, Edytorstwo źródet historycznych, Warszawa 2014.

Wnęk Sławomir, Elita strzyżowska od schyłku XIX do połowy XX wieku. Wybrane zagadnienia, ,Strzyżowski Rocznik Muzealny”, 2 (2016) s. 189-234.

Ziobro Wojciech, Zapis Antoniego Dydyńskiego z 2 lutego 1808 r. - przyczynek do badań nad Fundacja stypendialna im. Antoniego Dydyńskiego w Godowej, „Prace Historyczne”, 46 (2019), z. 4, s. 837-857.

Zubrzycki Tadeusz, Rzeź galicyjska w r. 1846, Stanisławów 1910.

\section{Netografia}

Nagrobek ks. Józefa Twaroga (1816-1886), http://www.nieobecni.com.pl/index.php?s=grob\&id=177463 (dostęp: 22.04.2020).

Nicieja Stanisław S., Moje Kresy. Cmentarz w Drohobyczu, https://nto.pl/moje-kresy -cmentarz-w-drohobyczu/ar/9050733 (dostęp: 20.04.2020). 


\title{
REV. AUGUST NAHLIK (1812-1878). STRZYZOW PARISH PRIEST AND AN UNDERGROUND ACTIVIST
}

\begin{abstract}
The article presents the life of reverend August Nahlik (1812-1878) during his service as a parish priest of St. Catherine's parish in Rumno. There, he got involved in the independence movement, and then became one of the leading figures of the so-called conspiracy in Horozhanna, whose main goal was to spark a local uprising against the partitioners in Eastern Galicia. Together with other upheavals of this type throughout the entire Galicia, the conspiracy in Horozhanna was to become an important part of the nationwide independence spur being prepared by the Polish Democratic Society since the 1840 s. Unfortunately, in 1846 the conspiracy was discovered and bloodily suppressed by the peasants, and the incidents in Horozhanna are associated with other revolts taking place at the time, described in historiography as the Galician Slaughter. Rev. August Nahlik, along with other conspirators who managed to escape the peasants' attack, was sentenced to 15 years in one of the toughest prisons of the Austrian Empire - the Spielberg fortress. However, thanks to the amnesty announced in 1848, he regained his freedom and, after a year of suspension, was first appointed a parish priest of St. Lawrence's parish in Chyrow, and then in 1864 he was transferred to the western part of the Przemysl diocese, to the parish of Immaculate Conception of the Blessed Virgin Mary and Corpus Christi in Strzyzow. There, he significantly contributed to the revival of the religious life of the parish, as well as to the restoration of the former glory of the temple, devastated in the Josephine times. He managed the parish in Strzyzow until his death in 1878 . The content of the article is additionally enriched by the edition of the last will of Rev. August Nahlik from 1878, which has been preserved in Feliks Misky's notarial deeds, and a previously unpublished photograph of the priest from the collection of the Polish Academy of Sciences.
\end{abstract}

Keywords: Strzyzow parish; parish priest; Galicia; last will; independence movement; Galician Slaughter; Eastern Galicia; August Nahlik 